Article

\title{
Equol Pretreatment Protection of SH-SY5Y Cells against $A \beta$ (25-35)-Induced Cytotoxicity and Cell-Cycle Reentry via Sustaining Estrogen Receptor Alpha Expression
}

\author{
Meng-Chao Tsai ${ }^{1,+}{ }^{+}$, Shyh-Hsiang Lin ${ }^{2,3,4,+}$, Kiswatul Hidayah ${ }^{2}$ and Ching-I Lin ${ }^{5, *}$ (i) \\ 1 Department of Psychiatry, Taoyuan General Hospital, Taoyuan 33004, Taiwan; mctsai1981@gmail.com \\ 2 School of Nutrition and Health Sciences, Taipei Medical University, Taipei 11042, Taiwan; \\ lin5611@tmu.edu.tw (S.-H.L.); kiswatul.hidayah@gmail.com (K.H.) \\ 3 Master Program in Food Safety, Taipei Medical University, Taipei 11042, Taiwan \\ 4 Research Center of Geriatric Nutrition, Taipei Medical University, Taipei 11042, Taiwan \\ 5 Department of Nutrition and Health Sciences, Kainan University, Taoyuan 33857, Taiwan \\ * Correspondence: drcilin@gmail.com or cilin@mail.knu.edu.tw; Tel.: +886-3-341-2500 (ext.6193); \\ Fax: +886-3-270-5904 \\ + Meng-Chao Tsai and Shyh-Hsiang Lin equally contributed to this work.
}

Received: 2 August 2019; Accepted: 23 September 2019; Published: 3 October 2019

\begin{abstract}
Alzheimer's disease. Exposure to this peptide may result in reentry into the cell cycle leading to cell death. The phytoestrogen equol has similar biological effects as estrogen without the side effects. This study investigated the possible mechanism of the neuron cell-protecting effect of equol during treatment with A $\beta$. SH-SY5Y neuroblastoma cells were treated with either $1 \mu \mathrm{M}$ S-equol or $10 \mathrm{nM} 17 \beta$-estradiol for $24 \mathrm{~h}$ prior to 1 $\mu \mathrm{M} A \beta$ (25-35) exposure. After $24 \mathrm{~h}$ exposure to $\mathrm{A} \beta$ (25-35), a significant reduction in cell survival and a reentry into the cell cycle process accompanied by increased levels of cyclin D1 were observed. The expressions of estrogen receptor alpha $(\mathrm{ER} \alpha)$ and its coactivator, steroid receptor coactivator-1 (SRC-1), were also significantly downregulated by A $\beta$ (25-35) in parallel with activated extracellular signal-regulated kinase (ERK)1/2. However, pretreatment of cells with S-equol or $17 \beta$-estradiol reversed these effects. Treatment with the ER antagonist, ICI-182,780 $(1 \mu \mathrm{M})$, completely blocked the effects of S-equol and $17 \beta$-estradiol on cell viability, ER $\alpha$, and ERK1/2 after A $\beta$ (25-35) exposure. These data suggest that $S$-equol possesses a neuroprotective potential as it effectively antagonizes $A \beta$ (25-35)-induced cell cytotoxicity and prevents cell cycle reentry in SH-SY5Y cells. The mechanism underlying S-equol neuroprotection might involve ER $\alpha$-mediated pathways.
\end{abstract}

Keywords: S-equol; $17 \beta$-estradiol; estrogen receptor alpha; cell cycle; $\beta$-Amyloid; Alzheimer's disease

\section{Introduction}

Neuronal cell death is an important feature of human neurodegenerative diseases such as Alzheimer's disease (AD). This cell death is considered to occur as a consequence of aberrant activation of the cell cycle in neurodegeneration [1]. Under normal conduction, the cell cycle is tightly controlled by specific regulatory proteins. For instance, cyclins and cyclin-dependent kinases (CDKs) are two key classes of regulatory molecules that determine a cell's progress in the cell cycle [2]. As a key regulator of the G1-S transition, cyclin D1 interacts with CDK4 to form the cyclin D1-CDK4 complex and moves to the nuclei, thereby promoting cell cycle progression. Normal adult neuron cells never reenter the cell cycle (but stay in the $\mathrm{G}_{0}$ stage) and are thus recognized as permanently postmitotic cells [3]. Conversely, 
neurons reenter the cycle, undergo DNA replication, and die after they are exposed to DNA-damaging agents, oxidative stress, or certain neurotoxins such as beta-amyloid $(A \beta)$ aggregates [3]. The $A \beta$ peptide is the major component of senile plaque derived from the A $\beta$ precursor protein (APP); this peptide is a neuropathological hallmark of $\mathrm{AD}$ [4]. There are numerous different $\mathrm{A} \beta$ species including $A \beta(1-40), A \beta(1-42)$, and $A \beta$ (25-35). The $A \beta$ (25-35) fragment is universally used in research as it has been found to elicit profound toxic manifestations in elderly people and to physiologically play a role in $\mathrm{AD}$ [5]. It has been previously shown that cell cycle activation accompanied by the upregulation of cyclin D1 in primary cultured rat cortical neurons was observed in response to exposure to $A \beta$ (25-35) and that such activation was followed by apoptotic neuronal death [6]. To elucidate the possible intracellular signaling pathway involved in the activation of the cell cycle by $\mathrm{A} \beta$, extracellular signal-regulated kinase (ERK) 1/2-related pathways are the major focus of the present study because there is evidence of the involvement of ERK1/2 activation in A $\beta$-induced neuronal cell death [7]. It has been documented that activation of ERK 1/2 appears to be critical for G1 to $S$ phase progression in cell cycle regulation [8]. A previous study showed that the overexpression of ERK 1/2 in cells exposed to $\mathrm{A} \beta$ was followed by an elevation in cyclin D1 expression, which resulted in changes in the cell-cycle distribution, particularly in the G1-S phase [9].

ERK1/2 is also the target of the regulatory action of estrogen and its regulation requires interaction with the known estrogen receptors (ERs), ER $\alpha$ and $E R \beta$ [10]. In addition to the reproductive system, both $E R \alpha$ and $E R \beta$ are broadly expressed in nonreproductive systems including the central nervous system [11]. Particularly, brain regions such as the hypothalamus, amygdala, and hippocampus appear to have distinct expression patterns of both ER subtypes [12]. Although it is recognized that ER $\beta$ is the predominant receptor in the hippocampus, where its absence has an impact on memory and cognitive function [13], ER $\alpha$ co-exists, and its coregulation may be important for ER $\beta$ to fulfill its cellular roles [14]. In other words, ER $\beta$ collaborating with ER $\alpha$ in its molecular actions is crucial for estrogen-mediated beneficial effects on hippocampus-dependent memory and cognition. The ER $\alpha$ subtype is of particular interest in the present study as it exhibits stronger transcription activity than $\mathrm{ER} \beta$ and thus appears to be functionally superior to $\mathrm{ER} \beta$ in the modulation of age-related memory decline [13-15]. It is noteworthy that ER $\alpha$ diminishing in the hippocampus with age leads to a decrease in the relative expression of $\operatorname{ER} \alpha$ and $E R \beta$, and nuclear ER $\alpha$-mediated effects, all of which are putative molecular mechanisms for age-related memory decline in the presence of low estrogen levels [13]. In this regard, the molecular actions of both ER subtypes have been reported to be involved in the neuroprotection of estrogen against the pathogenic processes of AD [16]. Evidence suggests that estrogen is capable of protecting against $A \beta$-induced toxicity through ER $\alpha$-mediated signaling pathways [17]. Moreover, the other major neuropathological hallmark of AD is intracellular aggregates of hyperphosphorylated Tau protein, which has recently been found to interact with ER $\alpha$ potentiating the reduction of ER $\alpha$ 's transcriptional activity [18]. SRC-1 is one of the nuclear receptor coactivators which enhance the transcriptional activity of ERs to manipulate the relevant molecular events [19]. Studies performed in a human astrocytoma cell line demonstrated that estradiol treatment increased the cell number through the mediation of $\operatorname{ER} \alpha$, whereas the coactivator silencing by RNA interference of SRC-1 was able to block this effect [19].

Equol is a metabolite of daidzein, one of the major isoflavones in soybean food products, and is known as an ERs agonist [20]. Equol is capable of inducing transcriptional responses, especially through the binding of ER $\alpha$ [21]. The oral bioavailability of equol in humans seems to be high, resulting in a plasma concentration of $0.4 \sim 2 \mu \mathrm{M}$ after taking a single bolus of $2 \mathrm{mg}$ of equol [22]. Consumption of phytoestrogens has been found to avoid many side effects from estrogens [23]. Intriguingly, equol has been shown to be a promising neuroprotectant in in vitro models, and its neuroprotective effects are exerted through anti-neuroinflammatory mechanisms with the regulation of relevant signaling pathways at molecular levels [24]. However, whether the cell cycle regulatory event and ER-dependent signaling pathways involve the neuroprotective properties of equol remains an enigma. Thus, in this study, we investigated the effects of equol on protecting SH-SY5Y cells against 
$\mathrm{A} \beta$-induced perturbations and the cellular mechanisms underlying equol's neuroprotective action in cell cycle events and ER pathways.

\section{Materials and Methods}

\subsection{Cell Culture}

Human SH-SY5Y neuroblastoma cells were cultured at $37^{\circ} \mathrm{C}$ and $5 \% \mathrm{CO}_{2}$ in Dulbecco's modified Eagle medium (DMEM) (Invitrogen ${ }^{\mathrm{TM}}$, Life Technologies, Grand Island, NY, USA) mixed with F12 (Invitrogen ${ }^{\mathrm{TM}}$, Life Technologies, Grand Island, NY, USA), 10\% fetal bovine serum (FBS) (Biowest LLC, Miami, FL, USA), and glutamine (Biological Industries, Kibbutz Beit Haemek, Israel). The medium was changed twice per week. Cells were grown to $80 \%$ confluence before treatment.

\subsection{Treatments}

A $\beta$ (25-35) (Sigma Aldrich, St. Louis, MO, USA) was dissolved in sterile distilled water at a concentration of $1 \mathrm{mM}$, then incubated in a capped vial at $37^{\circ} \mathrm{C}$ for 5 days to allow formation of the aggregated form. It was then stored frozen at $-20^{\circ} \mathrm{C}$ until use. $17 \beta$-Estradiol, S-equol, and ICI-182,780 (all from Cayman Chemical, Ann Arbor, MI, USA) were dissolved in 99.5\% ethanol to make stock solutions, which were used for experiments at a final concentration of $10 \mathrm{nM}$ for estradiol and 1 $\mu \mathrm{M}$ for equol and ICI-182,780 in culture medium. It should be noted that no cytotoxic effect of the vehicle (99.5\% ethanol) per se on cells was observed via the analysis of cell viability in our preliminary experiments that were conducted to determine the appropriate concentrations of the aforementioned treatments for the present study.

To induce cell death, cells were incubated with (A $\beta$ ) or without (C) $1 \mu \mathrm{M} \mathrm{A} \beta$ (25-35) for $24 \mathrm{~h}$. To study the effects of estradiol (E2) and equol (Eq), cells were preincubated with estradiol (E2 $+\mathrm{A} \beta)$ or equol $(\mathrm{Eq}+\mathrm{A} \beta)$ for $24 \mathrm{~h}$ prior to $\mathrm{A} \beta(25-35)$ exposure. Estradiol was used as a positive control and ICI-182,780 was used as an ER antagonist. It was added $1 \mathrm{~h}$ before the estradiol or equol treatment.

\subsection{Cell Viability Analysis}

Cell viability was assessed using a modified 3-[4,5-dimethylthiazol-2]-2,5 diphenyltetrazolium bromide (MTT) assay (Sigma, St. Louis, MO, USA). Cells were seeded in 24-well dishes at a seeding density of $2 \times 10^{5}$ cells/well. After treatment, $300 \mu \mathrm{L}$ of the MTT solution $(5 \mathrm{mg} / \mathrm{mL})$ was added to each well and incubated at $37^{\circ} \mathrm{C}$ for $3 \mathrm{~h}$. After removing the culture medium, $250 \mu \mathrm{L}$ of dimethyl sulfoxide (DMSO) was added to each well to dissolve the formazan, and then $200 \mu \mathrm{L}$ of the solution was moved to a 96-well dish. The optical density was measured at $570 \mathrm{~nm}$ using a microplate reader. The absorbance of the control group was considered to have $100 \%$ cell viability.

\subsection{Protein Extraction and Quantification}

After treatment, cells were harvested, washed three times with PBS, and lysed using a cold RIPA lysis buffer supplemented with a protease inhibitor and an EDTA solution (Thermo, Hudson, $\mathrm{NH}$, USA) at a ratio of 100:1:1, then centrifuged at $13,000 \mathrm{rpm}$ and $4{ }^{\circ} \mathrm{C}$ for $30 \mathrm{~min}$. The supernatant was collected, and the protein concentration was estimated with a BCA Protein Assay Kit (Sigma, St. Louis, MO, USA) using BSA as the standard.

\subsection{Cell-Cycle Analysis}

Cells $\left(8 \times 10^{5}\right)$ were seeded in 6-well dishes. After treatment, cells were trypsinized, washed in PBS, and centrifuged at $2000 \times g$ at $25^{\circ} \mathrm{C}$ for $5 \mathrm{~min}$, and then they were washed with PBS at least twice. Cells were fixed in $70 \%$ ethanol overnight. Before removing the ethanol, samples were centrifuged at $11^{\circ} \mathrm{C}$ and 2200 $\times g$ for $10 \mathrm{~min}$. The pellet was then resuspended in $200 \mu \mathrm{L}$ of DNA extraction buffer (containing $192 \mathrm{~mL} 0.2 \mathrm{M} \mathrm{Na}_{2} \mathrm{HPO}_{4}$ and $8 \mathrm{~mL} 0.1 \mathrm{M}$ citric acid at $\mathrm{pH} 7.8$ ) and incubated for $30 \mathrm{~min}$ at $37^{\circ} \mathrm{C}$. PI dye (200 $\mu \mathrm{L}$, containing $0.1 \%$ Triton-X100, $100 \mu \mathrm{g} / \mathrm{mL}$ RNase-A, and $80 \mu \mathrm{g} / \mathrm{mL}$ PI in PBS) was 
added, gently mixed, and incubated for $30 \mathrm{~min}$ at room temperature in the dark. After removing the PI dye, samples were resuspended with $1 \mathrm{~mL}$ of cold PBS prior to analysis by flow cytometry.

\subsection{Western Blot Analysis}

A western blot analysis was performed to examine the expression levels of the proteins. Equal quantities $(30 \mu \mathrm{g})$ of protein were separated by $10 \%$ sodium dodecyl sulfate polyacrylamide gel electrophoresis (SDS-PAGE) and then transferred onto nitrocellulose membranes. After transfer, membranes were blocked with Tris-buffered saline (TBS) containing 0.1\% Tween-20 (TBST) and 5\% non-fat-milk for $1 \mathrm{~h}$. The membranes were then incubated with specific primary antibodies (Cell Signaling Technology, Danvers, MA, USA): Anti-cyclin D1 (1:1000), anti-p-ERK 1/2 (1:1000), anti-ERK $1 / 2$ (1:1000), anti-ER $\alpha$ (1:1000), anti-SRC-1 (1:1000), and anti- $\beta$-actin (1:5000) overnight at $4{ }^{\circ} \mathrm{C}$. After washing three times with TBST for $30 \mathrm{~min}$, membranes were incubated with an anti-rabbit (1:80000) or anti-mouse (1:5000) immunoglobulin G (IgG) secondary antibody (Sigma) for $1 \mathrm{~h}$, and then washed with TBST three times for $30 \mathrm{~min}$. Immunoreactive proteins were detected by enhanced chemiluminescence (ECL) (Bionovas, Toronto, Canada) Western blot detection system.

\subsection{Statistical Analysis}

Data are shown as the mean and standard deviation (SD). Statistical comparisons were performed using SAS 9.3 (Cary, NC, USA). One-way analysis of variance (ANOVA) and least squared difference (LSD) post-hoc analysis of multiple comparisons were used. The statistical significance was accepted at $p<0.05$.

\section{Results}

\subsection{Cell Viability}

As shown in Figure 1, the cell viability of the $A \beta$ group decreased to $62.6 \%$ compared to the $C$ group $(p<0.05)$, suggesting that A $\beta(25-35)$ is cytotoxic to SH-SY5Y cells in the present study. After pretreatment with equol $(\mathrm{Eq}+\mathrm{A} \beta)$, the cell viability was significantly increased by $9.6 \%$ compared to the $A \beta$ group, and the same effect was observed in the E2 group which exhibited increased cell viability of up to $12.9 \%$ compared to the $\mathrm{A} \beta$ group $(p<0.05)$. No cytotoxic effect on cells was found from the treatments of $17 \beta$-estradiol (E2) and S-equol (Eq). These findings indicate that Eq, like E2, had the potential to provide the neuroprotective effects against $A \beta$ cytotoxicity in vitro. Moreover, in order to confirm that the neuroprotective effects of S-equol and $17 \beta$-estradiol against $A \beta$ (25-35) cytotoxicity are mediated by the estrogen receptors, cells were pretreated with $1 \mu \mathrm{M}$ ER antagonist ICI-182,780 for $1 \mathrm{~h}$ prior to Eq or E2 treatment. In the presence of $A \beta(25-35)$, pretreatment with ER antagonism of ICI-182,780 prior to Eq or E2 treatments significantly abolished their effects on SH-SY5Y cell viability $(p<0.05)$. These results suggest that Eq and E2 antagonized the reduced cell viability-induced by A $\beta$ (25-35), at least in part, by mediating the ERs.

\subsection{Estrogen Receptor Alpha (ER $\alpha$ ) Protein Expression}

Figure 2 shows that $\mathrm{A} \beta(25-35)$ alone markedly reduced the protein expression of $\operatorname{ER} \alpha(p<0.05)$, whereas pretreatments of Eq and E2 significantly attenuated the decreased protein expressions of ER $\alpha$ induced by A $\beta(25-35)(p<0.05)$. However, in the presence of ICI-182,780, the effects of the Eq and E2 pretreatments on ER $\alpha$ expression were significantly blocked $(p<0.05)$.

\subsection{SRC-1 Protein Expression}

Figure 3 shows the effects of the Eq and E2 pretreatments on the expression of the estrogen receptor coactivator SRC-1. Treatment of $1 \mu \mathrm{M} \mathrm{A} \beta$ (25-35) (A $\beta)$ for $24 \mathrm{~h}$ significantly decreased the SRC-1 protein expression $(p<0.05)$. Pretreatment with either Eq or E2 significantly prevented A $\beta$ (25-35)-induced reduction in SRC-1 protein expression $(p<0.05)$. 


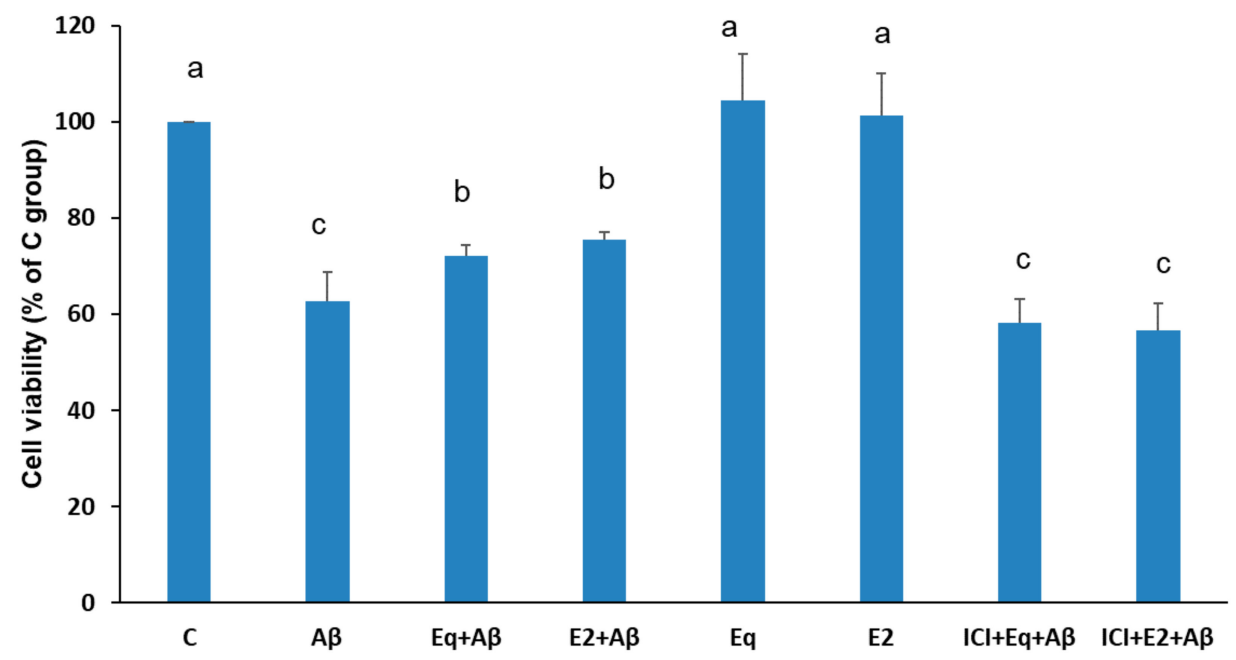

Figure 1. Cell viability of SH-SY5Y cells assessed with a modified 3-[4,5-dimethylthiazol-2]-2,5 diphenyltetrazolium bromide (MTT) assay. Data were analyzed by one-way ANOVA followed by the LSD post-hoc test and are representative of three independent experiments $(n=3)$. Values are presented as the mean $+\mathrm{SD}$. Bars with different letters significantly differ at a level of $p<0.05$. Eq, S-equol; E2, 17ß-estradiol; ICI, ICI-182,780.

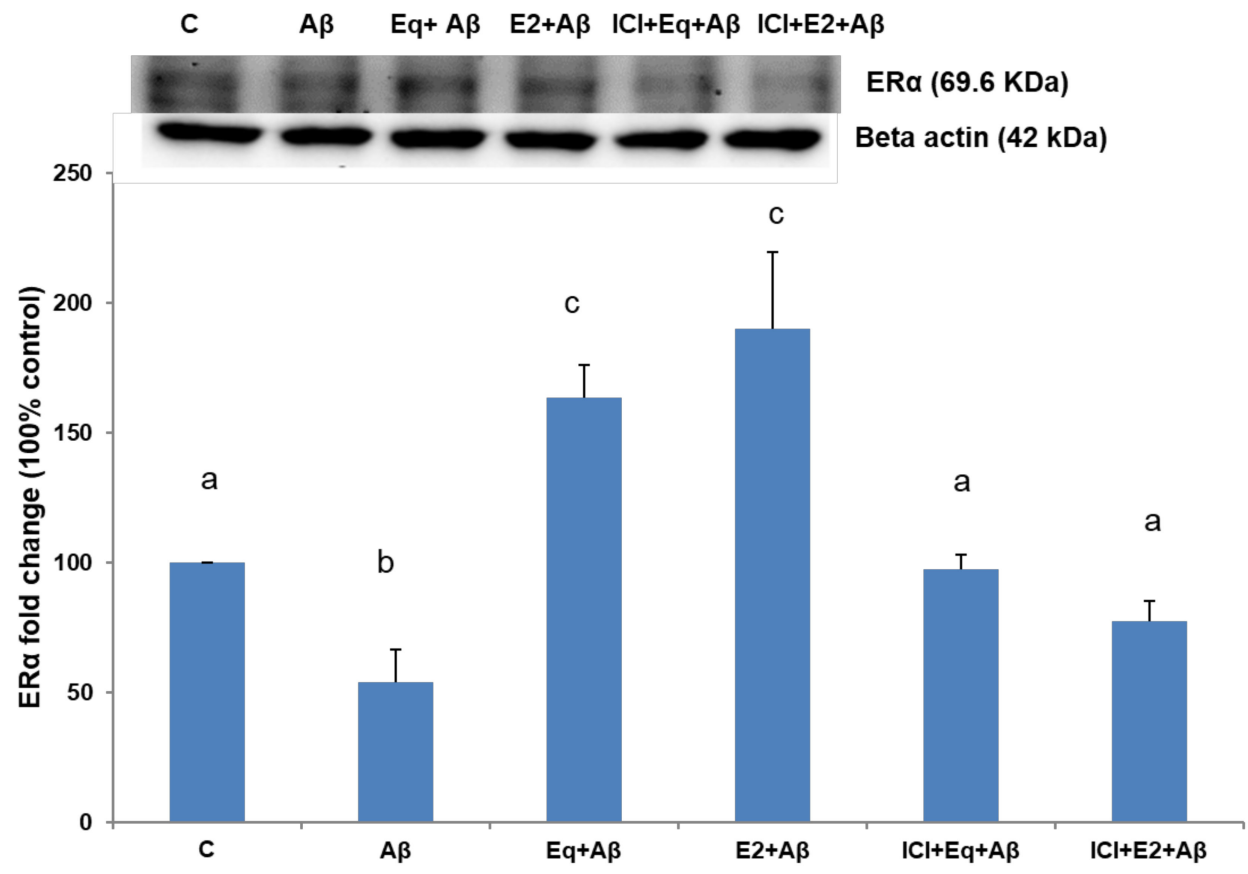

Figure 2. The estrogen receptor alpha (ER $\alpha)$ expressions of SH-SH5Y cells from different treatments. Data were analyzed by a one-way ANOVA followed by the LSD post-hoc test and are representative of three independent experiments $(n=3)$. Values are presented as the mean $+\mathrm{SD}$. Bars with different letters are significantly different at $p<0.05$.

\subsection{Cell Cycle}

Figure 4 shows the distribution of different phases of cell cycle. A significant increase of cells in the $S$ phase in the $A \beta$ group is observed compared to the $C$ group as well as a concomitant reduction of cells in the $G_{2} / M$ phases of the cycle (Figure 4). This result indicates that SH-SY5Y cells exposed to A $\beta$ (25-35) escaped from the $\mathrm{G}_{2} / \mathrm{M}$ phase. Pretreatment with either Eq $(\mathrm{Eq}+\mathrm{A} \beta)$ or E2 $(\mathrm{E} 2+\mathrm{A} \beta)$ showed a decreasing number of cells in the $S$ phase and a significantly increasing number in the $G_{2} / M$ phase compared to that in the $\mathrm{A} \beta$ group $(p<0.05)$. Cell cycle analysis showed that the cell cycle profiles were 
markedly altered by the treatment of $A \beta$ (25-35), and pretreatment with Eq or E2 significantly blocked A $\beta$ (25-35)-induced changes in the cell cycle profiles of the SH-SY5Y cells.

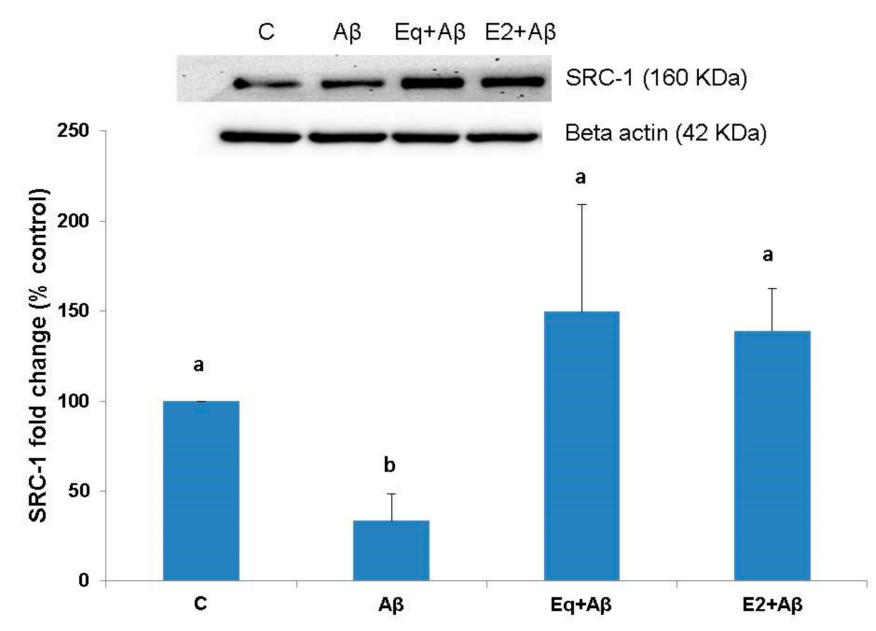

Figure 3. The SRC-1 expressions of SH-SH5Y cells from different treatments. Protein expressions were assessed by Western blotting. Data were analyzed by a one-way ANOVA followed by the LSD post-hoc test and are representative of three independent experiments $(n=3)$. Values are presented as the mean $+\mathrm{SD}$. Bars with different letters are significantly different at $p<0.05$.

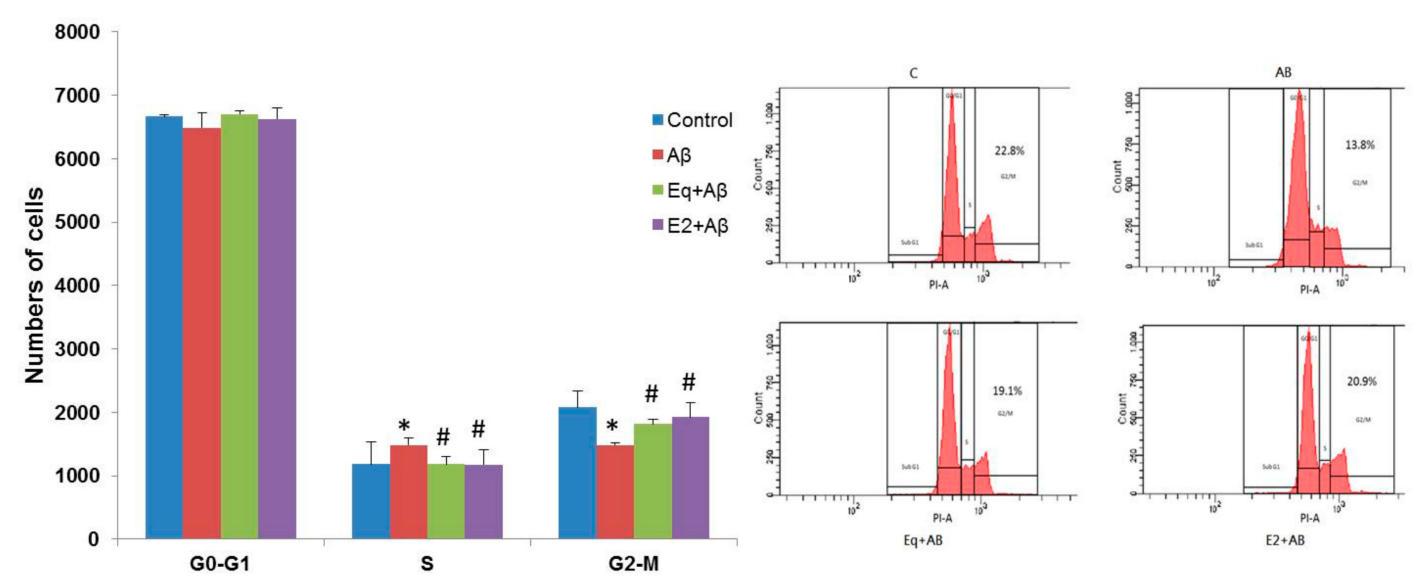

Figure 4. Cell cycle events of SH-SH5Y cells from different treatments. The cell cycle was assessed by PI staining with flow cytometry. Data were analyzed by one-way ANOVA followed by the LSD post-hoc test and are representative of three independent experiments $(n=3)$. Values are presented as the mean + SD. ${ }^{*} p<0.05$ vs. the control; ${ }^{\#} p<0.05$ vs. the $\mathrm{A} \beta$ group.

\subsection{Cyclin D1 Protein Expression}

Figure 5 shows the relative expressions of cyclin D1, a protein marker for the $G_{0} / G_{1}$ phase, in different treatments. The relative expression increased markedly after cells were treated with $A \beta$ (25-35) (A $\beta$ group) in comparison to the untreated cells (C group). A decreased level of expression was observed in cells which underwent $24-\mathrm{h} \mathrm{Eq}$ or $\mathrm{E} 2$ pretreatment $(\mathrm{Eq}+\mathrm{A} \beta$ group and $\mathrm{E} 2+\mathrm{A} \beta$ group, respectively), compared to the $\mathrm{A} \beta$ group $(p<0.05)$.

\subsection{Activation of ERK $1 / 2$}

Figure 6 shows that $A \beta(25-35)$ treatment significantly increased the expression of phosphorylated (p)-ERK $1 / 2(p<0.05)$. The pretreatments of Eq and E2 significantly prevented the A $\beta$ (25-35)-induced activation of ERK 1/2 $(p<0.05)$. On the other hand, when the ER activity was inhibited by ICI-182,780, the effect of Eq and E2 on deactivation of ERK $1 / 2$ was significantly reduced $(p<0.05)$. 


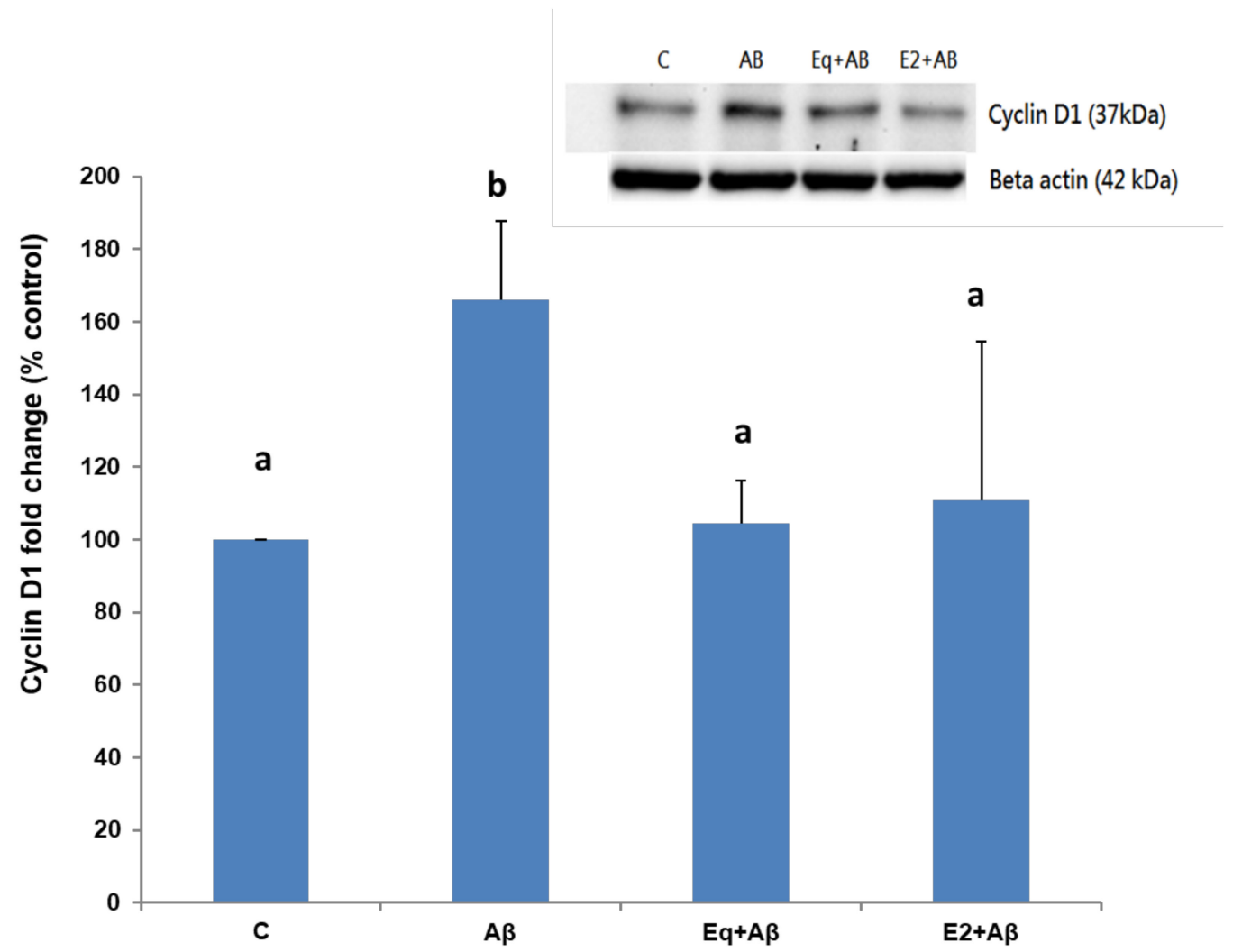

Figure 5. The cyclin D1 expressions of the SH-SH5Y cells from different treatments. Protein expressions were assessed by Western blotting. Data were analyzed by a one-way ANOVA followed by the LSD post-hoc test and are representative of three independent experiments $(n=3)$. Values are presented as the mean + SD. Bars with different letters are significantly different at $p<0.05$.

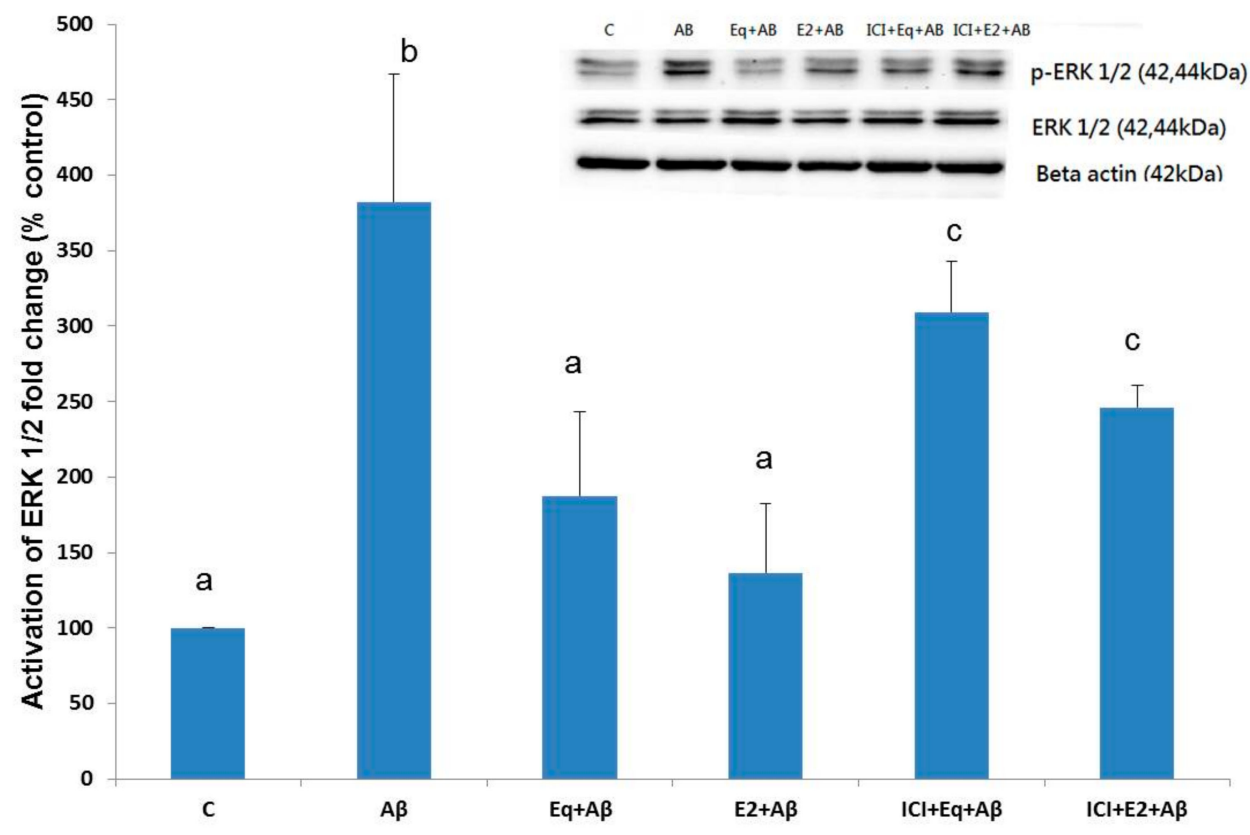

Figure 6. The phosphorylated (activated) ERK 1/2 expressions of SH-SH5Y cells from different treatments. Data were analyzed by a one-way ANOVA followed by the LSD post-hoc test and are representative of three independent experiments $(n=3)$. Values are presented as the mean $+\mathrm{SD}$. Bars with different letters are significantly different at $p<0.05$. 


\section{Discussion}

Evidence from previous clinical and experimental studies showed that estrogen replacement therapy may have beneficial effects on AD in postmenopausal women $[25,26]$. However, the use of estrogen as treatment is known to have side effects, such as the development of breast and endometrial cancers in women [23]. Phytoestrogens may be an alternative treatment for AD with fewer side effects. A previous study showed that the phytoestrogen, $\alpha$-zearanol, elevated the cell survival of $A \beta$ (25-35)-induced PC-12 cells by attenuating oxidative stress and apoptotic cell death in a manner similar to $17 \beta$-estradiol [27]. In the present study, both S-equol and $17 \beta$-estradiol were also found to increase cell survival followed by A $\beta$ (25-35) treatment. These results would predict that phytoestrogen, S-equol, possessed putative neuroprotective effects against A $\beta$ (25-35)-induced cytotoxicity on SH-SH5Y cells analogous to those of $17 \beta$-estradiol $[28,29]$. In addition, the result of the inhibition of ER with antagonist ICI-182,780 prior to the Eq and E2 treatments suggested that ER may have a role in the neuroprotection of S-equol and $17 \beta$-estradiol against A $\beta$ (25-35) cytotoxicity. The critical roles of ERs have been implicated in the cognitive function [14]. The loss of ER $\alpha$ expression has been noted to more likely contribute to AD-related memory impairment and amyloidogenesis [30,31]. Our observations showed the downregulation of ER $\alpha$ protein expression in SH-SH5Y cells exposed to A $\beta$ (25-35) alone, emphasizing the importance of the ER $\alpha$ functional role in response to $A \beta$ (25-35)-induced cytotoxicity. Under normal conditions, the ER $\alpha$ function can be enhanced by its coactivators, such as SRC-1, for efficient transcriptional regulation [32]. The decreased SRC-1 protein expression in the $A \beta$ (25-35)-treated group was seen in the present study showing the $A \beta$ (25-35)-induced disruption of the SRC-1 coactivator. These results support the notion that A $\beta$ (25-35)-induced perturbation of $\mathrm{ER} \alpha$ was further evident from the corresponding decrease in the expression of SRC-1. Furthermore, S-equol or 17 $\beta$-estradiol pretreatments efficiently attenuated the effects of $A \beta(25-35)$ in the current study, demonstrating that to provide a neuroprotective effect, equol binds with ER $\alpha$ and recruits SRC-1 to enhance its effect. On the other hand, the actions of both compounds were blocked by anti-estrogen ICI-182,780 in the present study, observing that ER $\alpha$ is required for the neuroprotective response of S-equol or $17 \beta$-estradiol to $A \beta(25-35)$ cytotoxicity.

$17 \beta$-estradiol binding to ER $\alpha$ is able to trigger transcriptional regulation of target genes, such as cyclin D1 [33]. In this regard, a recent study has reported that $17 \beta$-estradiol bound ER $\alpha$ has a role in controlling cell cycles [34]. In the present data, we presume that downregulated ER $\alpha$ expression in the presence of $A \beta$ (25-35) might partially contribute to aberrant cell cycles. In normal conditions, neuron cells are postmitotic and stay in the $G_{0}$ phase, as indicated by the downregulation of proteins related to the cell cycle [35]. For instance, cyclin D1, a protein marker of the $G_{0} / G_{1}$ phase, is expressed at the beginning of the G1 phase and continually accumulates in the nucleus during the G1 phase in the presence of the cell cycle reactivation [36]. When the cells progress into the S phase, cyclin D1 can secrete into the cytoplasm and its overexpression can reduce cell sizes and shorten the G1 phase resulting in the accelerated entry into the $S$ phase [37]. Likewise, our results showed that $A \beta(25-35)$ caused cells to leave the postmitotic phase and reenter the cell cycle in parallel with the increasing level of cyclin D1. This finding is in line with previous studies which found that $A \beta(25-35)$ toxicity induces cell-cycle reentry $[9,38]$. However, only a tendency toward a decrease in cell number of the G1 phase in the $\mathrm{A} \beta$-treated group was observed in this study. Such observation might be ascribed to a more rapid cell cycle progression in response to a higher level of cyclin D1 followed by A $\beta$ treatment as mentioned above. Alternatively, it is plausible that there is a high degree of variability in the G1-phase progression due to the differences in nature between cells, which indicates that the cell itself may enter into G1 or exit from G1 at different time points from its neighboring cells [39]. In presenilin (PS)-1 familial AD brains, the presence of cyclin D1 accumulation was observed to be linked to cell-cycle activation and subsequently led to cell death [40]. Our results are in accordance with previous findings showing that when exposed to $25 \mu \mathrm{M} \mathrm{A} \beta$ (25-35), SH-SY5Y cells accumulated in the S phase, indicating that they did not progress beyond the $S$ phase accompanied by apoptosis [9,41]. Taken together, we speculate that changes in ER $\alpha$ and cyclin D1 expressions concomitantly occurring with aberrant cell cycle reentry 
appear likely to underlie the cytotoxic mechanisms of $A \beta$ (25-35). Thus, apoptotic neuronal death is presumably the consequence of $A \beta$ (25-35)-induced cytotoxicity [42]. However, it is noteworthy that more recent evidence indicates neuronal cell death triggered by a cell cycle reentry event could be independent of an apoptotic mechanism in $\mathrm{AD}$ [43]. More in-depth investigation is warranted to resolve this discrepancy. Nevertheless, S-equol prevented A $\beta$ (25-35)-induced changes in the cell-cycle behavior, $\mathrm{ER} \alpha$, and cyclin D1 expressions, indicative of the neuroprotective potential of S-equol.

A common target for estrogen signaling and $A \beta$ neurotoxicity is ERK $1 / 2$ [9,10,44]. It was shown that ERK 1 and 2 are expressed in the pooled cerebrospinal fluid (CSF) of patients with AD, and elevated levels of ERK 1/2 in CSF are accompanied by increased levels of tau protein and the A $\beta 42$ peptide [45]. Rapid activation of ERK 1/2 was reported in SH-SY5Y neuroblastoma cells exposed to A $\beta$ (25-35) [9] and in mature hippocampal neurons [46]. Aberrant activation of ERK 1/2 was correlated with an elevated level of cyclin D1 that has been shown to be responsible for cell cycle reentry in neurons under $A \beta$-induced toxicity conditions, thereby potentiating the neuronal apoptosis responses [38]. The present data showed that $A \beta$ (25-35) triggered ERK $1 / 2$ activation, and pretreatments of S-equol and $17 \beta$-estradiol were able to prevent this response. In contrast, treatment with ICI-182,780 appeared to diminish the protective effects of S-equol and $17 \beta$-estradiol. These observations led us to propose that the neuroprotective mechanisms of the actions of S-equol and $17 \beta$-estradiol against $A \beta(25-35)$ cytotoxicity might be mediated by the ERK1/2 pathways via ER $\alpha$. Previous studies have shown that estrogen prevents cytotoxic effects of $A \beta$ by activating MAPK which regulates ERK $1 / 2$ expression and cyclin D1 to control cell cycle reentry $[9,29]$. Herein, we have shown that S-equol exhibited neuroprotective effects that mimicked the action of $17 \beta$-estradiol on A $\beta$ (25-35)-treated SH-SY5Y cells through preventing cell cycle reentry downregulating cyclin D1 and ER $\alpha$-mediated ERK 1/2 expressions, all of which might have involved suppression of $A \beta$ (25-35)-induced cell cycle reentry by S-equol or $17 \beta$-estradiol pretreatments in the current study.

\section{Conclusions}

This study concludes that A $\beta$ (25-35) caused diminished ER $\alpha$ levels, which mediated estrogen actions to disrupt normal cell cycle regulation and thus potentiates cell death. S-equol might act as a putative neuroprotective agent against $A \beta(25-35)$ cytotoxicity, and its neuroprotective role might be, at least in part, attributed to its estrogenic potency. The observed putative neuroprotective effects of equol were associated with sustaining ER $\alpha$ levels and cell survival in our cell models. Furthermore, the molecular mechanism underlying this putative neuroprotection of S-equol is shown to involve the suppression of cell cycle reentry which might be synergized with ER $\alpha$-involved activation of ERK 1/2 along with the prevented activation of cyclin D1.

Author Contributions: Conceptualization, M.-C.T., S.-H.L., K.H., and C.-I.L.; methodology, S.-H.L., K.H., and C.-I.L.; software, S.-H.L. and K.H.; validation, M.-C.T., S-H.L., K.H., and C.-I.L.; formal analysis, S.-H.L. and K.H.; resources, M.-C.T. and S-H.L.; data curation, S.-H.L., K.H., and C.-I.L.; writing-original draft preparation, review, and editing, C.-I.L.; supervision, M.-C.T. and S.-H.L.; project administration, M.-C.T. and C.-I.L.; funding acquisition, M.-C.T.

Funding: This study was funded by the Research Program of Taoyuan General Hospital, Taiwan; grant number PTH10542.

Conflicts of Interest: The authors declare that there is no conflict of interest regarding the publication of this paper.

\section{References}

1. Nagy, Z. Cell cycle regulatory failure in neurones: Causes and consequences. Neurobiol. Aging 2000, 21, 761-769. [CrossRef]

2. Frade, J.M.; Ovejero-Benito, M.C. Neuronal cell cycle: The neuron itself and its circumstances. Cell Cycle 2015, 14, 712-720. [CrossRef] [PubMed]

3. Herrup, K. The involvement of cell cycle events in the pathogenesis of Alzheimer's disease. Alzheimer's Res. Ther. 2010, 2, 13. [CrossRef] [PubMed] 
4. Querfurth, H.W.; LaFerla, F.M. Alzheimer's disease. N. Engl. J. Med. 2010, 362, 329-344. [CrossRef] [PubMed]

5. Clementi, M.E.; Marini, S.; Coletta, M.; Orsini, F.; Giardina, B.; Misiti, F. Abeta(31-35) and Abeta(25-35) fragments of amyloid beta-protein induce cellular death through apoptotic signals: Role of the redox state of methionine-35. FEBS Lett. 2005, 579, 2913-2918. [CrossRef] [PubMed]

6. Wang, J.; Zhang, Y.J.; Du, S. The protective effect of curcumin on Abeta induced aberrant cell cycle reentry on primary cultured rat cortical neurons. Eur. Rev. Med. Pharmacol. Sci. 2012, 16, 445-454. [PubMed]

7. Frasca, G.; Carbonaro, V.; Merlo, S.; Copani, A.; Sortino, M.A. Integrins mediate beta-amyloid-induced cell-cycle activation and neuronal death. J. Neurosci. Res. 2008, 86, 350-355. [CrossRef] [PubMed]

8. Mebratu, Y.; Tesfaigzi, Y. How ERK1/2 activation controls cell proliferation and cell death: Is subcellular localization the answer? Cell Cycle 2009, 8, 1168-1175. [CrossRef]

9. Frasca, G.; Chiechio, S.; Vancheri, C.; Nicoletti, F.; Copani, A.; Angela Sortino, M. Beta-amyloid-activated cell cycle in SH-SY5Y neuroblastoma cells: Correlation with the MAP kinase pathway. J. Mol. Neurosci. 2004, 22, 231-236. [CrossRef]

10. Mannella, P.; Brinton, R.D. Estrogen receptor protein interaction with phosphatidylinositol 3-kinase leads to activation of phosphorylated Akt and extracellular signal-regulated kinase $1 / 2$ in the same population of cortical neurons: A unified mechanism of estrogen action. J. Neurosci. 2006, 26, 9439-9447. [CrossRef]

11. Paterni, I.; Granchi, C.; Katzenellenbogen, J.A.; Minutolo, F. Estrogen receptors alpha (ERalpha) and beta (ERbeta): Subtype-selective ligands and clinical potential. Steroids 2014, 90, 13-29. [CrossRef] [PubMed]

12. Jung, M.E.; Gatch, M.B.; Simpkins, J.W. Estrogen neuroprotection against the neurotoxic effects of ethanol withdrawal: Potential mechanisms. Exp. Biol. Med. 2005, 230, 8-22. [CrossRef] [PubMed]

13. Foster, T.C. Role of estrogen receptor alpha and beta expression and signaling on cognitive function during aging. Hippocampus 2012, 22, 656-669. [CrossRef] [PubMed]

14. Bean, L.A.; Ianov, L.; Foster, T.C. Estrogen receptors, the hippocampus, and memory. Neuroscientist 2014, 20, 534-545. [CrossRef] [PubMed]

15. Carroll, J.C.; Pike, C.J. Selective estrogen receptor modulators differentially regulate Alzheimer-like changes in female 3xTg-AD mice. Endocrinology 2008, 149, 2607-2611. [CrossRef]

16. Zhao, L.; Wu, T.W.; Brinton, R.D. Estrogen receptor subtypes alpha and beta contribute to neuroprotection and increased Bcl-2 expression in primary hippocampal neurons. Brain Res. 2004, 1010, 22-34. [CrossRef]

17. Kim, H.; Bang, O.Y.; Jung, M.W.; Ha, S.D.; Hong, H.S.; Huh, K.; Kim, S.U.; Mook-Jung, I. Neuroprotective effects of estrogen against beta-amyloid toxicity are mediated by estrogen receptors in cultured neuronal cells. Neurosci. Lett. 2001, 302, 58-62. [CrossRef]

18. Wang, C.; Zhang, F.; Jiang, S.; Siedlak, S.L.; Shen, L.; Perry, G.; Wang, X.; Tang, B.; Zhu, X. Estrogen receptor-alpha is localized to neurofibrillary tangles in Alzheimer's disease. Sci. Rep. 2016, 6, 20352. [CrossRef]

19. Gonzalez-Arenas, A.; Hansberg-Pastor, V.; Hernandez-Hernandez, O.T.; Gonzalez-Garcia, T.K.; Henderson-Villalpando, J.; Lemus-Hernandez, D.; Cruz-Barrios, A.; Rivas-Suarez, M.; Camacho-Arroyo, I. Estradiol increases cell growth in human astrocytoma cell lines through ERalpha activation and its interaction with SRC-1 and SRC-3 coactivators. Biochim. Biophys. Acta 2012, 1823, 379-386. [CrossRef]

20. Mueller, S.O.; Simon, S.; Chae, K.; Metzler, M.; Korach, K.S. Phytoestrogens and their human metabolites show distinct agonistic and antagonistic properties on estrogen receptor alpha (ERalpha) and ERbeta in human cells. Toxicol. Sci. 2004, 80, 14-25. [CrossRef]

21. Setchell, K.D.; Clerici, C. Equol: Pharmacokinetics and biological actions. J. Nutr. 2010, 140, 1363s-1368s. [CrossRef] [PubMed]

22. Setchell, K.D.; Zhao, X.; Shoaf, S.E.; Ragland, K. The pharmacokinetics of S-(-)equol administered as SE5-OH tablets to healthy postmenopausal women. J. Nutr. 2009, 139, 2037-2043. [CrossRef] [PubMed]

23. Morabito, N.; Crisafulli, A.; Vergara, C.; Gaudio, A.; Lasco, A.; Frisina, N.; D’Anna, R.; Corrado, F.; Pizzoleo, M.A.; Cincotta, M.; et al. Effects of genistein and hormone-replacement therapy on bone loss in early postmenopausal women: A randomized double-blind placebo-controlled study. J. Bone Miner. Res. 2002, 17, 1904-1912. [CrossRef] [PubMed]

24. Subedi, L.; Ji, E.; Shin, D.; Jin, J.; Yeo, J.H.; Kim, S.Y. Equol, a Dietary Daidzein Gut Metabolite Attenuates Microglial Activation and Potentiates Neuroprotection In Vitro. Nutrients 2017, 9, 207. [CrossRef]

25. Merlo, S.; Spampinato, S.F.; Sortino, M.A. Estrogen and Alzheimer's disease: Still an attractive topic despite disappointment from early clinical results. Eur. J. Pharmacol. 2017, 817, 51-58. [CrossRef] 
26. Christensen, A.; Pike, C.J. Age-dependent regulation of obesity and Alzheimer-related outcomes by hormone therapy in female 3xTg-AD mice. PLoS ONE 2017, 12, e0178490. [CrossRef]

27. Dong, Y.; Yang, N.; Liu, Y.; Li, Q.; Zuo, P. The neuroprotective effects of phytoestrogen alpha-zearalanol on beta-amyloid-induced toxicity in differentiated PC-12 cells. Eur. J. Pharmacol. 2011, 670, 392-398. [CrossRef]

28. Zhao, L.; Mao, Z.; Brinton, R.D. A select combination of clinically relevant phytoestrogens enhances estrogen receptor beta-binding selectivity and neuroprotective activities in vitro and in vivo. Endocrinology 2009, 150, 770-783. [CrossRef]

29. Valles, S.L.; Borras, C.; Gambini, J.; Furriol, J.; Ortega, A.; Sastre, J.; Pallardo, F.V.; Vina, J. Oestradiol or genistein rescues neurons from amyloid beta-induced cell death by inhibiting activation of p38. Aging Cell 2008, 7, 112-118. [CrossRef]

30. Hwang, C.J.; Yun, H.M.; Park, K.R.; Song, J.K.; Seo, H.O.; Hyun, B.K.; Choi, D.Y.; Yoo, H.S.; Oh, K.W.; Hwang, D.Y.; et al. Memory Impairment in Estrogen Receptor alpha Knockout Mice Through Accumulation of Amyloid-beta Peptides. Mol. Neurobiol. 2015, 52, 176-186. [CrossRef]

31. Tang, Y.; Min, Z.; Xiang, X.J.; Liu, L.; Ma, Y.L.; Zhu, B.L.; Song, L.; Tang, J.; Deng, X.J.; Yan, Z.; et al. Estrogen-related receptor alpha is involved in Alzheimer's disease-like pathology. Exp. Neurol. 2018, 305, 89-96. [CrossRef] [PubMed]

32. Tetel, M.J.; Acharya, K.D. Nuclear receptor coactivators: Regulators of steroid action in brain and behaviour. J. Neuroendocrinol. 2013, 25, 1209-1218. [CrossRef]

33. Cicatiello, L.; Addeo, R.; Sasso, A.; Altucci, L.; Petrizzi, V.B.; Borgo, R.; Cancemi, M.; Caporali, S.; Caristi, S.; Scafoglio, C.; et al. Estrogens and progesterone promote persistent CCND1 gene activation during G1 by inducing transcriptional derepression via c-Jun/c-Fos/estrogen receptor (progesterone receptor) complex assembly to a distal regulatory element and recruitment of cyclin D1 to its own gene promoter. Mol. Cell. Biol. 2004, 24, 7260-7274. [CrossRef] [PubMed]

34. JavanMoghadam, S.; Weihua, Z.; Hunt, K.K.; Keyomarsi, K. Estrogen receptor alpha is cell cycle-regulated and regulates the cell cycle in a ligand-dependent fashion. Cell Cycle 2016, 15, 1579-1590. [CrossRef] [PubMed]

35. Negis, Y.; Unal, A.Y.; Korulu, S.; Karabay, A. Cell cycle markers have different expression and localization patterns in neuron-like PC12 cells and primary hippocampal neurons. Neurosci. Lett. 2011, 496, 135-140. [CrossRef]

36. Sumrejkanchanakij, P.; Tamamori-Adachi, M.; Matsunaga, Y.; Eto, K.; Ikeda, M.A. Role of cyclin D1 cytoplasmic sequestration in the survival of postmitotic neurons. Oncogene 2003, 22, 8723-8730. [CrossRef]

37. Quelle, D.E.; Ashmun, R.A.; Shurtleff, S.A.; Kato, J.Y.; Bar-Sagi, D.; Roussel, M.F.; Sherr, C.J. Overexpression of mouse D-type cyclins accelerates G1 phase in rodent fibroblasts. Genes Dev. 1993, 7, 1559-1571. [CrossRef]

38. Modi, P.K.; Komaravelli, N.; Singh, N.; Sharma, P. Interplay between MEK-ERK signaling, cyclin D1, and cyclin-dependent kinase 5 regulates cell cycle reentry and apoptosis of neurons. Mol. Biol. Cell 2012, 23, 3722-3730. [CrossRef]

39. Jackman, J.; O'Connor, P.M. Methods for synchronizing cells at specific stages of the cell cycle. Curr. Protoc. Cell Biol. 2001. [CrossRef]

40. Malik, B.; Currais, A.; Andres, A.; Towlson, C.; Pitsi, D.; Nunes, A.; Niblock, M.; Cooper, J.; Hortobagyi, T.; Soriano, S. Loss of neuronal cell cycle control as a mechanism of neurodegeneration in the presenilin-1 Alzheimer's disease brain. Cell Cycle 2008, 7, 637-646. [CrossRef]

41. Copani, A.; Condorelli, F.; Caruso, A.; Vancheri, C.; Sala, A.; Giuffrida Stella, A.M.; Canonico, P.L.; Nicoletti, F.; Sortino, M.A. Mitotic signaling by beta-amyloid causes neuronal death. FASEB J. 1999, 13, 2225-2234. [CrossRef] [PubMed]

42. Millucci, L.; Ghezzi, L.; Bernardini, G.; Santucci, A. Conformations and biological activities of amyloid beta peptide 25-35. Curr. Protein Pept. Sci. 2010, 11, 54-67. [CrossRef] [PubMed]

43. Barrio-Alonso, E.; Hernandez-Vivanco, A.; Walton, C.C. Cell cycle reentry triggers hyperploidization and synaptic dysfunction followed by delayed cell death in differentiated cortical neurons. Sci. Rep. 2018, 8, 14316. [CrossRef] [PubMed]

44. Fitzpatrick, J.L.; Mize, A.L.; Wade, C.B.; Harris, J.A.; Shapiro, R.A.; Dorsa, D.M. Estrogen-mediated neuroprotection against beta-amyloid toxicity requires expression of estrogen receptor alpha or beta and activation of the MAPK pathway. J. Neurochem. 2002, 82, 674-682. [CrossRef] [PubMed] 
45. Spitzer, P.; Schieb, H.; Kamrowski-Kruck, H.; Otto, M.; Chiasserini, D.; Parnetti, L.; Herukka, S.K.; Schuchhardt, J.; Wiltfang, J.; Klafki, H.W. Evidence for Elevated Cerebrospinal Fluid ERK1/2 Levels in Alzheimer Dementia. Int. J. Alzheimer's Dis. 2011, 2011, 739847. [CrossRef] [PubMed]

46. Rapoport, M.; Ferreira, A. PD98059 prevents neurite degeneration induced by fibrillar beta-amyloid in mature hippocampal neurons. J. Neurochem. 2000, 74, 125-133. [CrossRef] 